ISSN 1678-3921

Journal homepage: www.embrapa.br/pab

For manuscript submission and journal contents, access: www.scielo.br/pab

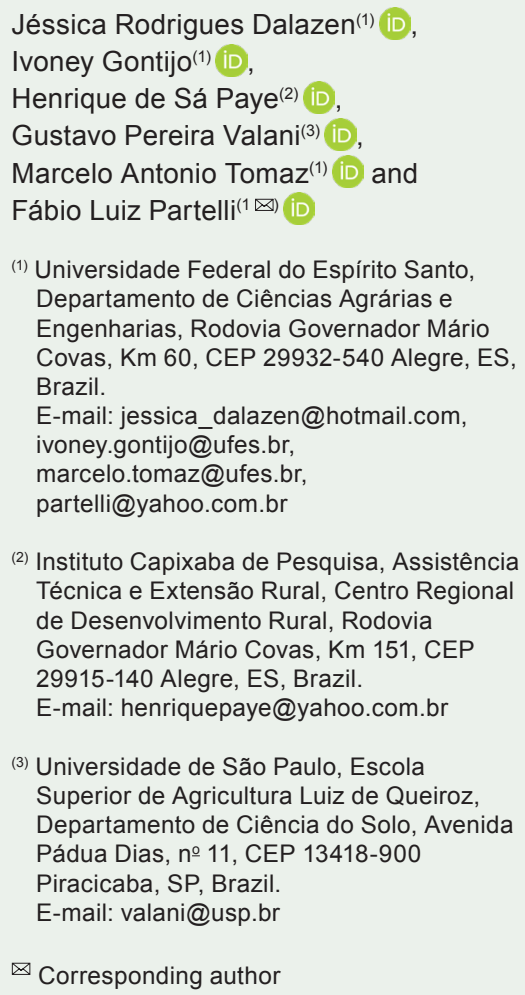

(2) Instituto Capixaba de Pesquisa, Assistência Técnica e Extensão Rural, Centro Regional de Desenvolvimento Rural, Rodovia Governador Mário Covas, Km 151, CEP 29915-140 Alegre, ES, Brazil.

E-mail: henriquepaye@yahoo.com.br

(3) Universidade de São Paulo, Escola Superior de Agricultura Luiz de Queiroz, Departamento de Ciência do Solo, Avenida Pádua Dias, no 11, CEP 13418-900 Piracicaba, SP, Brazil.

\section{Macronutrient dynamics in leaves and bunches of black pepper}

\begin{abstract}
The objective of this work was to determine the macronutrient dynamics in leaves and bunches of black pepper (Piper nigrum) throughout the plant reproductive cycles. The experiment was carried out in a commercial field of 'Bragantina' black pepper. Leaves and bunches were sampled every 21 days for one year, during two crop cycles. The bunches were sampled from the twenty eighth day after the appearance of inflorescences until the complete fruit maturation. Samples of leaves and bunches were dried, and the contents of $\mathrm{N}, \mathrm{P}, \mathrm{K}, \mathrm{Ca}, \mathrm{Mg}$, and $\mathrm{S}$ were determined. $\mathrm{N}, \mathrm{K}$, and $\mathrm{Ca}$ were the most common macronutrients found in the bunches and leaves of black pepper. The accumulation of dry matter in the bunches was similar for both cycles and it was adjusted to the linear and quadratic models. The accumulation and content of macronutrients followed the dry matter behavior trend. Macronutrient contents in leaves oscillate during the year, and $\mathrm{K}$ and $\mathrm{Mg}$ vary more than $\mathrm{N}$, $\mathrm{P}, \mathrm{Ca}$, and $\mathrm{S}$. The macronutrient contents in black pepper leaves and bunches depends on the plant vegetative stage, and this variation should be considered in the planning of the fertilization management.
\end{abstract}

Index terms: Piper nigrum, Bragantina cultivar, fertilization, reproductive cycle.

\section{Dinâmica de macronutrientes em folhas e cachos de pimenta-do-reino}

Resumo - O objetivo deste trabalho foi determinar a dinâmica de macronutrientes em folhas e cachos de pimenta-do-reino (Piper nigrum), ao longo dos ciclos reprodutivos da planta. O experimento foi realizado em uma lavoura comercial de pimenta-do-reino 'Bragantina'. Folhas e cachos foram amostrados a cada 21 dias, por um ano, durante dois ciclos de cultivo. Os cachos foram amostrados desde o vigésimo oitavo dia após o lançamento das inflorescências até a maturação completa dos frutos. As amostras de folhas e cachos foram secas, e os conteúdos de N, P, K, Ca, Mg e S foram determinados. $\mathrm{N}, \mathrm{K} \mathrm{e} \mathrm{Ca}$ foram os macronutrientes mais comuns nos cachos e nas folhas de pimenta-do-reino. O acúmulo de matéria seca nos cachos de pimenta-do-reino foi similar nos dois ciclos e foi ajustado aos modelos linear e quadrático. $\mathrm{O}$ acúmulo e o conteúdo de macronutrientes seguiram a tendência de comportamento da matéria seca. O conteúdo de macronutrientes nas folhas oscila durante o ano, e K e Mg variam mais do que N, P, Ca e S. O conteúdo de macronutrientes em folhas e cachos de pimenta-do-reino depende do estádio vegetativo da planta, e essa variação deve ser considerada no planejamento do manejo de adubação.

Termos para indexação: Piper nigrum, cultivar Bragantina, fertilização, ciclo reprodutivo. 


\section{Introduction}

Black pepper [Piper nigrum L. (Piperaceae)] is a perennial plant of Indian origin. Its fruit (peppercorn) is a condiment globally used to add flavor and aroma to food and has therapeutic properties. These traits are mainly attributed to piperine, a bioactive component with several different pharmacological activities, such as anticarcinogenic, analgesic, anti-inflammatory, antioxidant, antibacterial and anti-asthma properties (Butt et al., 2013; Tasleem et al., 2014; Wang et al., 2014; Rehman et al., 2015; Abukawsar et al., 2018).

The black pepper plant is widely cultivated in many tropical regions, such as India, Indonesia, Vietnam, Brazil, and China. According to the International Pepper Community (2018), the global production of black pepper in 2017 was 488.5 thousand metric tons. Brazil stands out as one of the largest producers of this pepper species, currently ranking fourth in the world market (International Pepper Community, 2018). In 2017, the Brazilian production was higher than 78 thousand metric tons, and about $47 \%$ from this total came from the state of Espírito Santo, making it the largest producer in the country (LSPA, 2017). The higher black pepper yield in Espírito Santo can be attributed to a broader use of technological implements, since approximately $80 \%$ of the cultivated area is irrigated (Partelli, 2009).

Most of the current black pepper strategies for fertilization do not consider periods of higher nutritional demand, thus, fertilization rate is applied equally within different periods. However, there is the need to add inputs more efficiently. The lack of knowledge on these factors and the excessive use of fertilizers may lead to higher costs of production, environmental issues, and lower efficiency in the overall crop production system, making the activity less profitable (Partelli et al., 2014).

Black pepper is a nutrient-demanding crop, especially during the reproductive phase. In the Amazon region, the species demand for macronutrients follows the descending order $\mathrm{N}>\mathrm{K}>\mathrm{Ca}>\mathrm{Mg}>\mathrm{P}$, as highlighted by Veloso \& Carvalho (1999). Extracted and accumulated quantities of macronutrients in $P$. nigrum plants vary according to each absorbed element, as well as to crop cultivar (Veloso et al., 2000), crop age, and plant organs and tissues (Veloso \& Carvalho, 1999). Studies on other crops have suggested that the fruit demand for macronutrients occurs throughout the reproductive period and may be influenced by management conditions (Dubberstein et al., 2016; Covre et al., 2018), and by crop genotype (Partelli et al., 2014). In black pepper plants, however, such influences are still unknown.

This work hypothesized that the leaf content and the macronutrient accumulation of black pepper bunches vary in different periods during the crop cycle. The study of such variation may support future recommendations and adjustments to black pepper fertilization, to improve the activity sustainability.

The objective of this work was to determine the macronutrient dynamics in leaves and bunches of black pepper throughout the reproductive cycles.

\section{Materials and methods}

The experiment was carried out during two crop cycles, in a commercial field of 'Bragantina' black pepper (Piper nigrum) located in the municipality of São Mateus, in the state of Espírito Santo, Brazil (18 $46^{\prime} 48^{\prime \prime} \mathrm{S}, 39^{\circ} 52^{\prime} 32^{\prime \prime} \mathrm{W}$, at $23 \mathrm{~m}$ altitude). The climate of the region, according to the Köppen-Geiger's classification, is Aw, tropical climate with dry winter and rainy summer (Alvares et al., 2013). The average, maximum, and minimum air temperatures, global solar radiation, rainfall and relative air humidity, during the studied period (Figure 1), were obtained from the meteorological station, located at $15 \mathrm{~km}$ from the experimental area, in the experimental farm of the Universidade Federal do Espírito Santo.

The soil in the study site is a Latossolo Amarelo distrocoeso, according to the Brazilian soil system (Santos et al., 2018), corresponding to a Ferralsol (IUSS Working Group WRB, 2015). The distribution of soil-particle size and the soil chemical properties were as follows: $679.5 \mathrm{~g} \mathrm{~kg}^{-1}$ sand; $60.5 \mathrm{~g} \mathrm{~kg}^{-1}$ silt; 260 $\mathrm{g} \mathrm{kg}^{-1}$ clay; $\mathrm{pH}$ in water, $5.05 ; 52 \mathrm{mg} \mathrm{dm}^{-3} \mathrm{P} ; 95 \mathrm{mg} \mathrm{dm}^{-3}$ $\mathrm{K}^{+} ; 8 \mathrm{mg} \mathrm{dm}^{-3} \mathrm{~S} ; 4 \mathrm{cmol}_{\mathrm{c}} \mathrm{dm}^{-3} \mathrm{Ca}^{2+} ; 0.35 \mathrm{cmol}_{\mathrm{c}} \mathrm{dm}^{-3}$ $\mathrm{Mg}^{2+} ; 0.5 \mathrm{cmol}_{\mathrm{c}} \mathrm{dm}^{-3} \mathrm{Al}^{3+} ; 5.9 \mathrm{cmol}_{\mathrm{c}} \mathrm{dm}^{-3} \mathrm{H}+\mathrm{Al} ; 2.2$ dag $\mathrm{dm}^{-3}$ organic matter; $4.62 \mathrm{cmol}_{\mathrm{c}} \mathrm{dm}^{-3}$ sum $\mathrm{f}$ bases; $5.12 \mathrm{cmol}_{\mathrm{c}} \mathrm{dm}^{-3}$ effective CEC; $13.87 \mathrm{cmol}_{\mathrm{c}} \mathrm{dm}^{-3} \mathrm{CEC}$ $\mathrm{pH} 7.0 ; 46.03 \%$ base saturation.

The 'Bragantina' black pepper was used in the experiment, as it is the most used cultivar in the region. Plant of about three years of age were cultivated under full sunlight, in $3.5 \times 1.8 \mathrm{~m}$ spacing, in relief varying from smooth to wavy. Farming managements included weed control by using herbicides, liming, topdressing 
mineral fertilization, pruning, and drip irrigation (Serrano et al., 2006; Prezotti et al., 2007). The crop fertilization was applied yearly with about $400 \mathrm{~kg} \mathrm{ha}^{-1}$ $\mathrm{N}, 80 \mathrm{~kg} \mathrm{ha}^{-1} \mathrm{P}_{2} \mathrm{O}_{5}$, and $320 \mathrm{~kg} \mathrm{ha}^{-1} \mathrm{~K}_{2} \mathrm{O}$, distributed over each year.

Black pepper bunches were sampled over two crop cycles in order to assess the macronutrient dynamics. For both cycles, 200 inflorescences were marked in 10 plants. In each evaluation, nine bunches were randomly collected, and each three bunches formed a composite sample of three replicates each. During the first crop cycle, sampling started on 04/17/2017, approximately 28 days after the appearance of the inflorescences. The samples were taken at intervals of about 21 days, until the complete maturation of fruit, ending on 11/13/2017 (238 days after the inflorescences appearance), which led to a total of eleven sampling periods during the first crop cycle. During the second crop cycle, bunches marking and sampling were performed the same way as during the first cycle. It started on 11/13/2017 and ended on 04/30/2018 (196 days after the inflorescences appearance), which led to a total of nine sampling periods in the second crop cycle. The last period for bunches sampling, in both periods, was performed when fruit were still colored green but fully grown. There were a total of 20 sampling studied periods (11 in the first and nine in the second period). It is important to note that the second cycle was 42 days shorter than the first one, as fruit had fully grown earlier.

In order to assess the macronutrient contents in the leaves, a total of 120 leaves were sampled in each one of the same sampling periods of bunch sampling. Three composite samples of 40 leaves each were taken in each sampling period. The leaves were sampled from the upper middle thirds of the same plants marked for bunch evaluation. This approach resulted in 20 sampling periods over one year. The reason for assessing leaf content over one year was to verify the leaf-macronutrient content behavior in an annual cycle.

The collected plant materials (leaves and skypes) were dried in a forced-ventilation oven, at $70^{\circ} \mathrm{C}$, until constant mass was reached, and were subsequently weighed on a precision scale $(0.001 \mathrm{~g})$. The $\mathrm{N}, \mathrm{P}, \mathrm{K}$, $\mathrm{Ca}, \mathrm{Mg}$, and $\mathrm{S}$ contents of the bunches and leaves were obtained in a laboratory, according to the methodology described by Teixeira et al. (2017). Macronutrient accumulation was considered as the relation between macronutrient content and dry mass throughout the studied period.

The resulting data for macronutrient content in the leaves, and for macronutrient accumulation in the bunches were subjected to the analysis of variance, at $5 \%$ probability, using the software Sisvar version 5.6 (Ferreira, 2019). Subsequently, a regression analysis was performed to obtain the accumulation of macronutrients in the bunches. The graphs were created based on the means and standard error, with
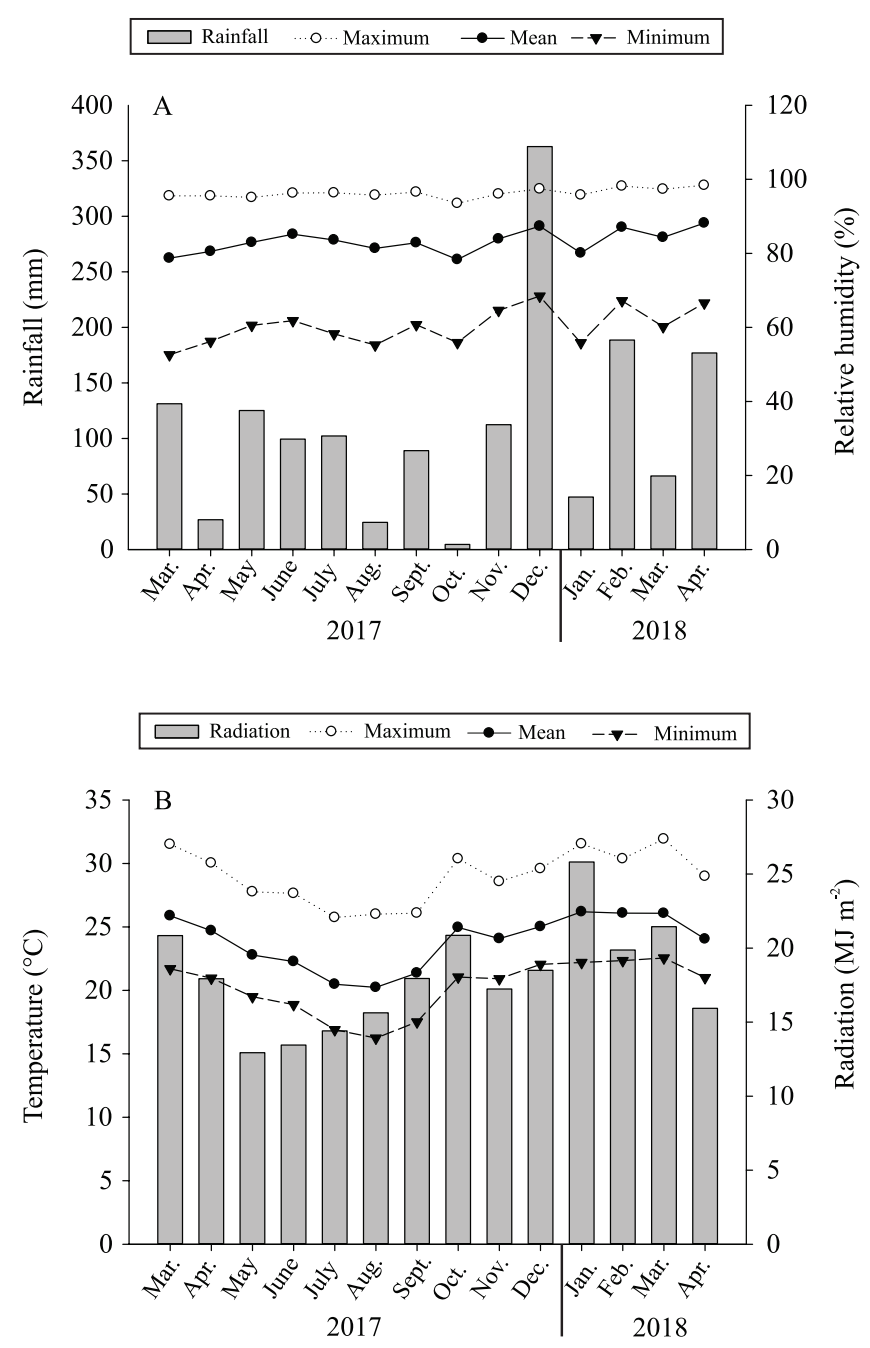

Figure 1. Total precipitation and average values for maximum, mean, and minimum relative humidity (A); and radiation and average values for maximum, mean, and minimum air temperature, recorded at the meteorological station in São Mateus, in the state of Espírito Santo, Brazil, from March 2017 to April 2018. 
the aid of the SigmaPlot software, version 11.0 (Systat Software Inc., San Jose, CA, USA).

\section{Results and discussion}

The macronutrient content in the leaves differed significantly between different periods (Table 1). The content of $\mathrm{K}$ and $\mathrm{Mg}$ in the leaves varied more than those of N, P, Ca, and S (Figure 2). It is interesting to note that $\mathrm{K}$ and $\mathrm{Ca}$ showed opposite trends, as the lowest contents of $\mathrm{Ca}$ and highest contents of $\mathrm{K}$ were observed from April to July 2017 and from October to April 2018, the period known as the production phase of black pepper. This trend was also observed in a work with Piper hispidinervum, in which an increase of the calcium content in leaves together with the omission of potassium was found (Viégas et al., 2013).

Calcium is immobile in the phloem and, therefore, it depends on the Ca that comes from the xylem, following the plant transpiration flux. Thus, higher-Ca contents are expected to be found in the leaves (especially in older ones) than in the fruit. However, $\mathrm{K}$ - that is not part of any organic structure in the plant - is mobile in the phloem, justifying its opposite behavior in relation to Ca (Taiz et al., 2014).

According to the leaf reference table for black pepper, the ideal contents of $\mathrm{N}, \mathrm{P}, \mathrm{K}, \mathrm{Ca}, \mathrm{Mg}$, and $\mathrm{S}$, in the flowering period, are 28, 1.4, 20, 10, 3, and $2 \mathrm{~g} \mathrm{~kg}^{-1}$, respectively (Prezotti et al., 2007). Thus, most macronutrient values found in the leaves during the flowering period, in both studied cycles, are in accordance with the standard values, except for $\mathrm{N}$ and $\mathrm{S}$, which showed lower contents than the recommended ones in the second cycle, and $\mathrm{Ca}$, which showed higher content also in the second cycle (Figure 2). These results of the present work are similar to those for the 'Guajarina' black pepper, at 29 months of age, in the Amazon region, and lower than those shown in the same work for the 'Bragantina' black pepper (Veloso et al., 2000).

The nutrient contents during a crop cycle are known to be unbalanced, as they vary according to the nutritional demand in the different physiological stages of the plant growth (Horel et al., 2019), and the extraction of nutrients to fruit is responsible for most of this variation, since the fruit become the preferential nutrient drains during the reproductive phase (Dubberstein et al., 2016). During the reproductive phase, black pepper fruit go through different phenological stages that begin after the appearance of the inflorescences, followed by the development of the bunches, until the complete maturation is reached.

In the bunches, $\mathrm{N}, \mathrm{K}$, and $\mathrm{Ca}$ were the macronutrients with the highest contents in both cycles, followed by $\mathrm{Mg}$, P, and S (Figure 3). Our results corroborate those by Veloso \& Carvalho (1999), who found that high-N, $\mathrm{K}$, and $\mathrm{Ca}$ contents were transposed to fruit of black pepper, and that the demand for the transposition of macronutrient to fruit included $\mathrm{N}, \mathrm{K}, \mathrm{Ca}, \mathrm{Mg}$, and $\mathrm{P}$, with S ranking last.

The highest-N contents in the bunches, 33 and $34 \mathrm{~g} \mathrm{~kg}^{-1}$, were found in the first sampling periods, which decreased to values close to 22 and $23 \mathrm{~g} \mathrm{~kg}^{-1}$ by the end of the experiment (Figure $3 \mathrm{~A}$ ), and they are similar to those found by Veloso \& Carvalho (1999), which corresponded to $22.8 \mathrm{~g} \mathrm{~kg}^{-1}$ for black

Table 1. Analysis of variance for macronutrient content in leaves and bunches of 'Bragantina' black pepper (Piper nigrum), during two cycles (from 04/17/2017 to 11/13/2017 and from 11/13/2017 to 04/30/2018), in São Mateus, in the state of Espírito Santo, Brazil.

\begin{tabular}{|c|c|c|c|c|c|c|c|}
\hline \multirow{2}{*}{$\begin{array}{l}\text { Sources of } \\
\text { variation }\end{array}$} & \multirow{2}{*}{$\begin{array}{c}\text { Dry mass } \\
\left(\mathrm{g} \mathrm{kg}^{-1}\right)\end{array}$} & \multicolumn{6}{|c|}{ Mean square value } \\
\hline & & $\mathrm{N}$ & $\mathrm{P}$ & $\mathrm{K}$ & $\mathrm{Ca}$ & $\mathrm{Mg}$ & $\mathrm{S}$ \\
\hline & & \multicolumn{6}{|c|}{ Leaf content } \\
\hline Sampling period & - & $4.05^{*}$ & $0.06 * *$ & $33.42 * *$ & $44.95 * *$ & $0.37 *$ & $0.08^{* *}$ \\
\hline \multirow[t]{2}{*}{$\mathrm{CV}(\%)$} & - & 5.06 & 8.87 & 11.73 & 8.16 & 11.80 & 7.34 \\
\hline & & \multicolumn{6}{|c|}{ Content in the bunches } \\
\hline Cycle 1 & $8.89 * *$ & $52.23 * *$ & $0.49 * *$ & $18.61 * *$ & $19.91 * *$ & $1.28 * *$ & $0.18^{* *}$ \\
\hline Cycle 2 & $4.69 * *$ & $46.52 * *$ & $1.11^{* *}$ & $70.89 * *$ & $30.17 * *$ & $1.19 * *$ & $0.01^{* *}$ \\
\hline $\mathrm{CV}_{\text {cyclel }}(\%)$ & 13.39 & 5.60 & 9.46 & 8.16 & 11.92 & 7.71 & 10.36 \\
\hline $\mathrm{CV}_{\text {cycle2 }}(\%)$ & 26.81 & 4.55 & 5.39 & 7.40 & 11.67 & 8.34 & 9.46 \\
\hline
\end{tabular}

$\mathrm{CV}$, coefficient of variation. *, ** Significantly different, at 5 and $1 \%$ probability, respectively. 
pepper 'Guajarina' at 28 months of age, in the Amazon region. The black pepper bunches are the parts of the plant that accumulates the most nitrogen (Veloso \& Carvalho, 1999; Ann, 2012). A positive response to $\mathrm{N}$ application was observed with the production of black pepper bunches from different cultivars (Veloso et al., 2000). This large amount of $\mathrm{N}$ found in the fruit is possibly associated with its important role as a constituent of amino acids, as it is present
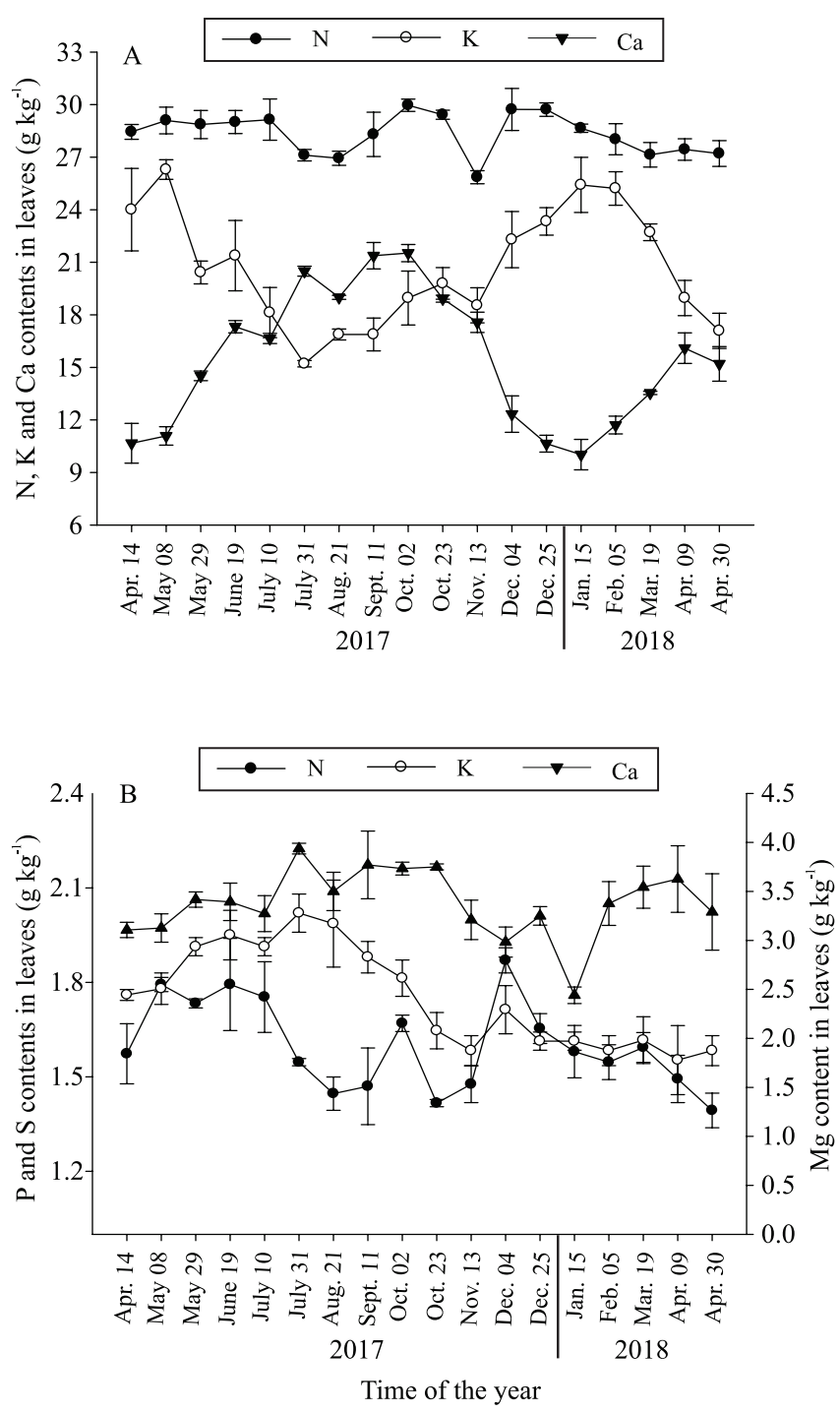

Figure 2. Contents of macronutrients in 'Bragantina' black pepper (Piper nigrum) leaves in two reproductive cycles, from April 2017 to April 2018: (A), N, K, and Ca; and (B), $\mathrm{P}, \mathrm{Mg}$, and $\mathrm{S}$. The first reproductive cycle occurred from $04 / 17 / 2017$ to $11 / 13 / 2017$, and the second one, from $11 / 13 / 2017$ to $04 / 30 / 2018$, in São Mateus, in the state of Espírito Santo, Brazil. in many nonprotein compounds, such as enzymes, photosynthetic pigments, secondary metabolites, polyamines, and vitamins (Pandey, 2015); thus, the unbalanced supply of this macronutrient may limit the crop productive potential.

In the present study, the lowest-K contents in the fruit - 15 and $16 \mathrm{~g} \mathrm{~kg}^{-1}$ - obtained in the last sampling periods, corresponding to the first and second cycles (Figure $3 \mathrm{C}$ ), were higher than those $\left(12.5 \mathrm{~g} \mathrm{~kg}^{-1}\right)$ found by Veloso \& Carvalho (1999). The high-K content of black pepper fruit of the present work corroborates the findings by other studies (Veloso \& Carvalho, 1999; Veloso et al., 2000; Ann, 2012). Potassium plays an important role in the formation of fruit and is often described as a quality element for agricultural production. It is related to the transport of photoassimilates in the phloem (Pandey, 2015), which explains why it is one of the nutrients most present in fruit. In plants of the Annonaceae family, this element is required during the phase of fruit formation, in a significant way for the synthesis of carbohydrates and other compounds (São José et al., 2014). During fruiting, its demand is related to the content of other nutrients in the plant, especially N (Srinivasan, 2007), and the offer of $\mathrm{K}$ should meet the plants maximum demand before the fruit expansion (Ann, 2012).

After $\mathrm{N}$ and $\mathrm{K}$, calcium was the third most concentrated element in black pepper bunches (Figure 3 D), since the first sampling period. However, Ca contents were lower when compared to the first two macronutrients. Veloso \& Carvalho (1999) found 7.8 $\mathrm{g} \mathrm{kg}^{-1} \mathrm{Ca}$ contents in black pepper fruit at 28 months of age. In present work, the highest-Ca contents were 14 $\mathrm{g} \mathrm{kg}^{-1}$ in the inflorescence phase, which was evaluated from the second sampling onwards during the first sampling period, with a continuous decrease in the contents up to 105 days after inflorescence, stabilizing at approximately $8 \mathrm{~g} \mathrm{~kg}^{-1}$. In the second cycle, such decrease was more pronounced, reaching lower values that corresponded to $3 \mathrm{~g} \mathrm{~kg}^{-1}$ by the end of the sampling periods, 189 days after inflorescence.

Calcium is a macronutrient with an important role in the physiology of several plant species, with relevant performance in functions related to the structural composition of macromolecules, mainly in cell walls and membranes (Pandey, 2015), being indispensable for the good quality of the fruit growth from fertilization until their physiological maturity (São 

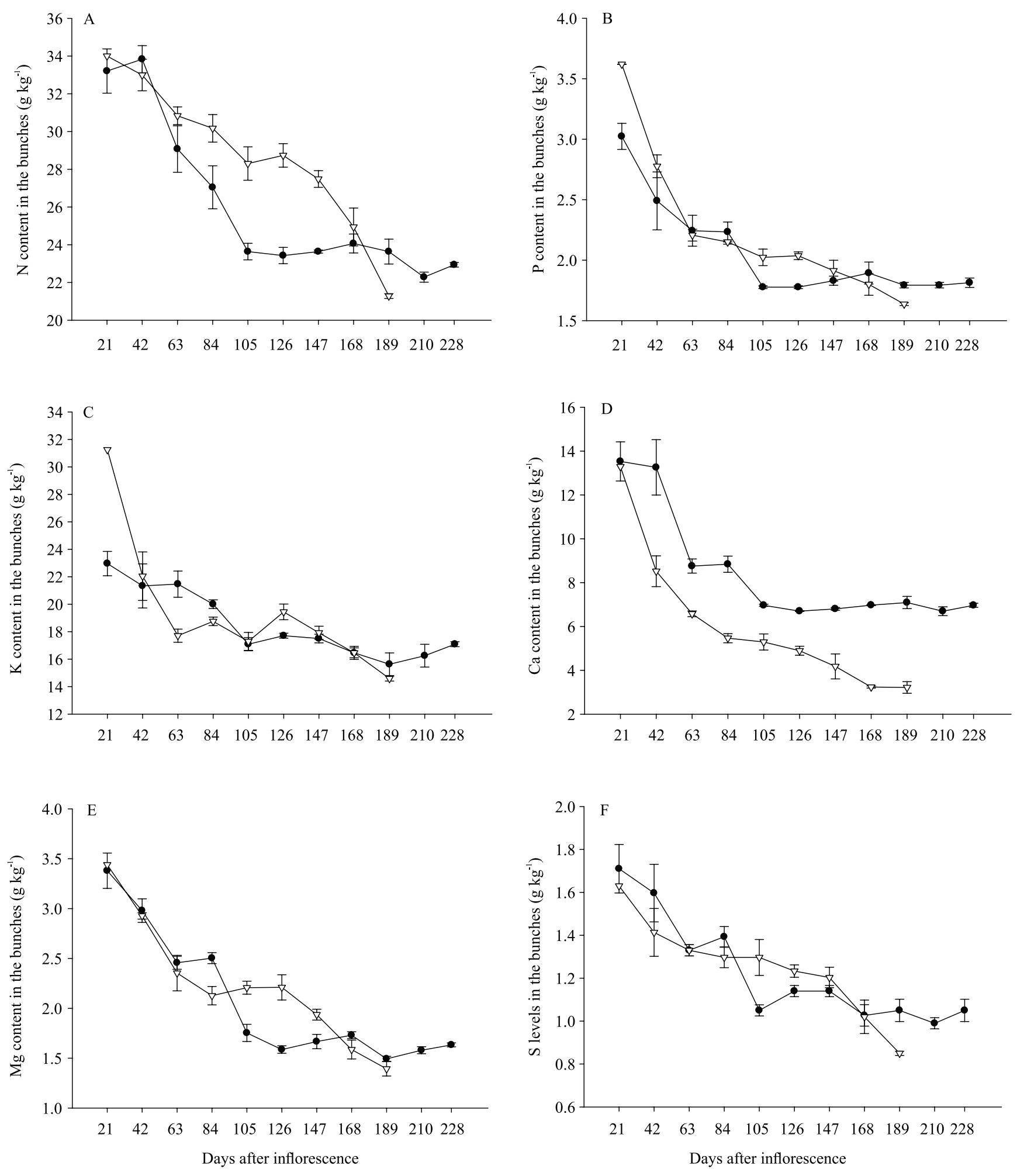

$$
\longrightarrow \text { Cycle } 1 \quad \nabla \text { Cycle } 2
$$

Figure 3. Macronutrient contents in 'Bragantina' black pepper (Piper nigrum) bunches over two reproductive cycles: (A), N; (B), P; (C), K; (D), Ca; (E), Mg; and (F), S. The first reproductive cycle occurred from 04/17/2017 to 11/13/2017, and the second one, from 11/13/2017 to 04/30/2018, in São Mateus, in the state of Espírito Santo, Brazil. 
José et al., 2014). Many studies attest to the relevance of this element for fruit of different crops, from their formation until physiological maturity, and its effects on their quality (Aular \& Natale, 2013; Gomes Júnior et al., 2018).

The $\mathrm{P}$ contents in the bunches (Figure $3 \mathrm{~B}$ ) were low, in comparison to the other macronutrients $(\mathrm{N}, \mathrm{K}$, and $\mathrm{Ca}$ ), accounting for 1.6 and $1.8 \mathrm{~g} \mathrm{~kg}^{-1}$ by the end of the evaluations, when fruit reached their harvesting stage, which corroborates the findings by Veloso \& Carvalho (1999), who, in general, found low-P content in all parts of the plant, with higher contents in fruit, corresponding to $2.18 \mathrm{~g} \mathrm{~kg}^{-1}$. The adequate supply of $\mathrm{P}$ may stimulate and increase the production of black pepper, according to Ann (2012). In the Amazon region, the fruit yield of the black pepper 'Guajarina' responded positively to $\mathrm{P}$ application, as verified by Veloso et al. (2000). Phosphorus is an essential nutrient for crop growth, as it is involved in several key functions of plants, including the energy transfer, photosynthesis, and processing of sugar and starch (Macintosh et al., 2019). Large amounts of $P$ are stored in the seed, such as phytic acid, acting on the embryo development, seed germination, and seedling growth (Pandey, 2015).

We observed that fruit of black pepper required small amounts of $\mathrm{Mg}$ and $\mathrm{P}$, which corroborates the results found by Veloso \& Carvalho (1999), who reported $1.9 \mathrm{~g} \mathrm{~kg}^{-1} \mathrm{Mg}$ contents in fruit, a value close to those obtained in the present work, which corresponded to approximately $1.5 \mathrm{~g} \mathrm{~kg}^{-1}$ in the last sampling periods, in both cycles (Figure $3 \mathrm{E}$ ). Magnesium is essential for the optimal functioning of plant metabolism, as it is the element that activates most enzymes, and it is involved in energy metabolism, with a fundamental role in the photosynthesis and respiration processes (Pandey, 2015). Black pepper plants took up only 35.4 $\mathrm{kg} \mathrm{ha}^{-1} \mathrm{Mg}$ per year from the soil, and only $20 \%$ of this total were used by leaves and bunches, according to Ann (2012).

The $\mathrm{S}$ content in the bunches (Figure $3 \mathrm{~F}$ ) decreased with time in both cycles, similarly to the other macronutrients. There was a relatively low variation between the maximum and minimum points of approximately $0.7 \mathrm{~g} \mathrm{~kg}^{-1}$ in each cycle. This variation differs from the result found for coffee berries, whose $\mathrm{S}$ contents varied greatly during different fruit stages in the Amazon (Dubberstein et al., 2016). However, we could not find any information in the literature on the transposition of this macronutrient by $P$. nigrum fruit. Although black pepper fruit require low-S quantities (as $\mathrm{P}$ and $\mathrm{Mg}$ ), this nutrient has specific and essential functions, acting as a constituent of amino acids, such as cysteine and methionine, and as an activator of enzymes, according to Pandey (2015), who reported that the required $\mathrm{S}$ amount is equally low for the good quality of the plant growth and ranges from 1 to 5 $\mathrm{g} \mathrm{kg}^{-1}$ in dry matter.

An overall analysis of both crop cycles showed that higher-macronutrient contents in bunches occurred in the first sampling periods, which is the phase understood as inflorescence, followed by a growing decline with less expressive rates at the end of the cycle, in the phase of fruit maturation (Figure 3).

The accumulation of dry mass increased over both cycles (Figure 4), with lower rates in the first sampling period, when fruit were still of small size and with little accumulation of dry mass, which contributed to a higher-macronutrient content. The expansion and maturation stages are characterized by cell expansion, when fruit increase in size and accumulate substances (Laviola et al., 2006). Thus, the nutrient contents in the bunches vary according to the increase of dry mass, that is, the amount of nutrients dilutes with the increase in the accumulation of dry mass.

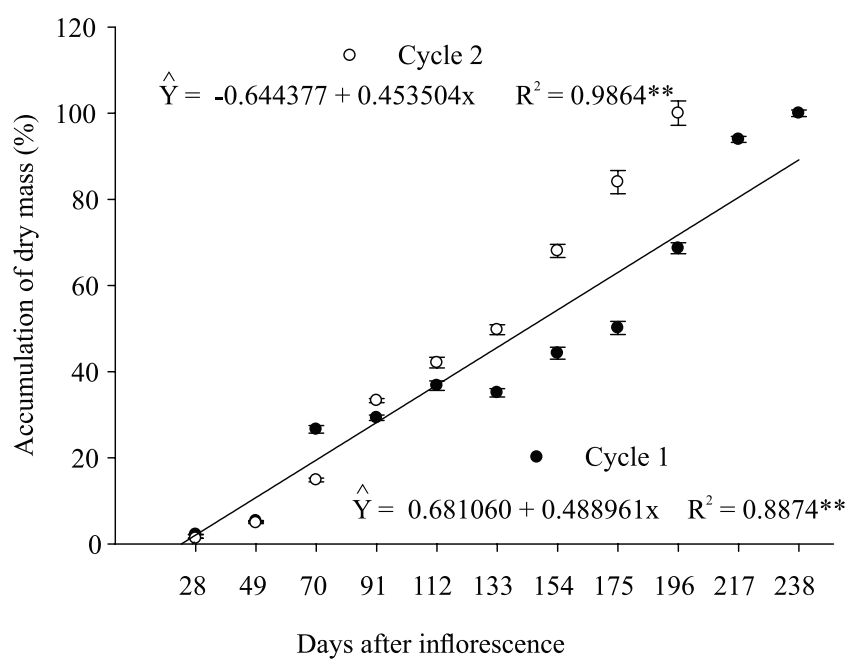

Figure 4. Accumulation of dry matter in 'Bragantina' black pepper (Piper nigrum) bunches over two reproductive cycles, the first one occurred from 04/17/2017 to 11/13/2017, and the second one, from 11/13/2017 to 04/30/2018, in São Mateus, in the state of Espírito Santo, Brazil. 
The accumulation curves allowed of the estimation of macronutrients extracted by the reproductive parts of the plants (bunches) during each stage of their development, starting 28 days after inflorescence (Figure 5). The linear and quadratic regression models were adjusted for all macronutrients analyzed, with $1 \%$ significance by the analysis of variance and high coefficient of determination, showing reduced accumulation rates in the initial phase of flowering, followed by gains in the expansion phase, and reaching the highest rates at the end of the fruiting cycle, which were similar in the two evaluated cycles and directly related to the accumulation of dry mass.

In other crops, such as Coffea canephora, the accumulation of macronutrients in fruit showed a sigmoidal behavior (Partelli et al., 2014; Covre et al., 2016; Dubberstein et al., 2016), differing from the findings of the present study. This response can be attributed to the bunches of the last sampling period, performed when fruit were fully grown and, although they had already reached their ideal harvesting stage, their skin was still colored green. After this moment, the tendency of accumulation is expected to stabilize, due to transformations that occur with the fruit ripening, including the degradation of compounds.

Nitrogen stands out as the most accumulated macronutrient in the two cycles, showing higher contents in the second one (Figure 5 A). Accumulation increased over time, following the trend of accumulation of dry mass, and reaching its maximum value by the end of the last sampling, at 238 and 196 days after inflorescence, in the first and second cycle, respectively, periods when the black pepper bunches accumulated 115.11 and $83.23 \mathrm{~g} \mathrm{~kg}^{-1} \mathrm{~N}$, values which correspond to $100 \%$ of the accumulated $\mathrm{N}$.

Potassium was the second most accumulated macronutrient in the bunches (Figure $5 \mathrm{~B}$ ). As with $\mathrm{N}$, the demand for $\mathrm{K}$ in the bunches increased over time, reaching the maximum accumulated value in the last sampling period, at 228 and 189 days after inflorescence, corresponding to 85.75 and $57.5 \mathrm{~g} \mathrm{~kg}^{-1} \mathrm{~K}$, and the highest increase was observed in the first cycle.

Calcium was the third most abundant macronutrient in the black pepper bunches (Figure $5 \mathrm{C}$ ). As nitrogen and potassium, Ca reached its maximum accumulation $(100 \%)$ in the last sampling period, at 238 and 196 days after inflorescence, with 34.96 and $12.59 \mathrm{~g} \mathrm{~kg}^{-1} \mathrm{Ca}$, also following the tendency of $\mathrm{N}$ and $\mathrm{K}$ in relation to its superior accumulation in the first cycle.

Phosphorus, $\mathrm{Mg}$, and $\mathrm{S}$ were the macronutrients for which accumulated values were the lowest ones in the bunches (Figure 5 D, E, F). The lowest accumulation rates were observed in the first samples ( 28 days after inflorescence), followed by an increasing behavior until the end of the evaluation period, 238 and 196 days after inflorescence, with $100 \%$ of the accumulated total, corresponding to $9.10 \mathrm{~g}$ in the first cycle, and $6.40 \mathrm{~g}$ in the second cycle for P (Figure $5 \mathrm{D}$ ); $8.20 \mathrm{~g}$ in the first cycle, and $5.45 \mathrm{~g}$ in the second cycle for $\mathrm{Mg}$ (Figure $5 \mathrm{E}$ ); and $5.27 \mathrm{~g}$ in the first cycle, and $3.32 \mathrm{~g}$ in the second cycle for $\mathrm{S}$ (Figure $5 \mathrm{~F}$ ), which was the least accumulated element.

According to our results, black pepper has more than one cycle per year, and each one has a different fruiting period. The first cycle occurred between April and October 2017 (238 days), while the second ranged from November 2017 to April 2018 (196 days). It may be noted that harvest took place 42 days earlier in the second cycle than the first one and, in both cycles, the last sampling of the black pepper bunches was performed at the same maturation point. Possibly, this event reflects the oscillations of climatic variables throughout the year.

An amount above the average hours of exposure to the sun, from the beginning until the end of the reproductive cycle of black pepper is harmful to the crop yield, but the exposure increase at the end of the cycle is beneficial, as it helps to promote the plant development and maturity, according to Kandiannan et al. (2011). In the first cycle, the end of the reproductive cycle coincided with the month of October, period of the year characterized by spring, when the days start to become longer. The second cycle, which began in November, at the end of spring, lasted through every day of summer, characterized as the season of the year in which the sun rises earlier and sets later, adding hours to the day, which may have influenced the crop cycle.

The maximum, mean, and minimum temperature values between April and August 2017 showed a decreasing trend, reaching the lowest values in July and August, followed by a recovery in September and October 2017 (Figure 1). Between the months of November 2017 and April 2018, the temperature values remained stable with little variation, and in of February 
and March 2018, corresponding to the same sampling period of the months of July and August 2017, the highest
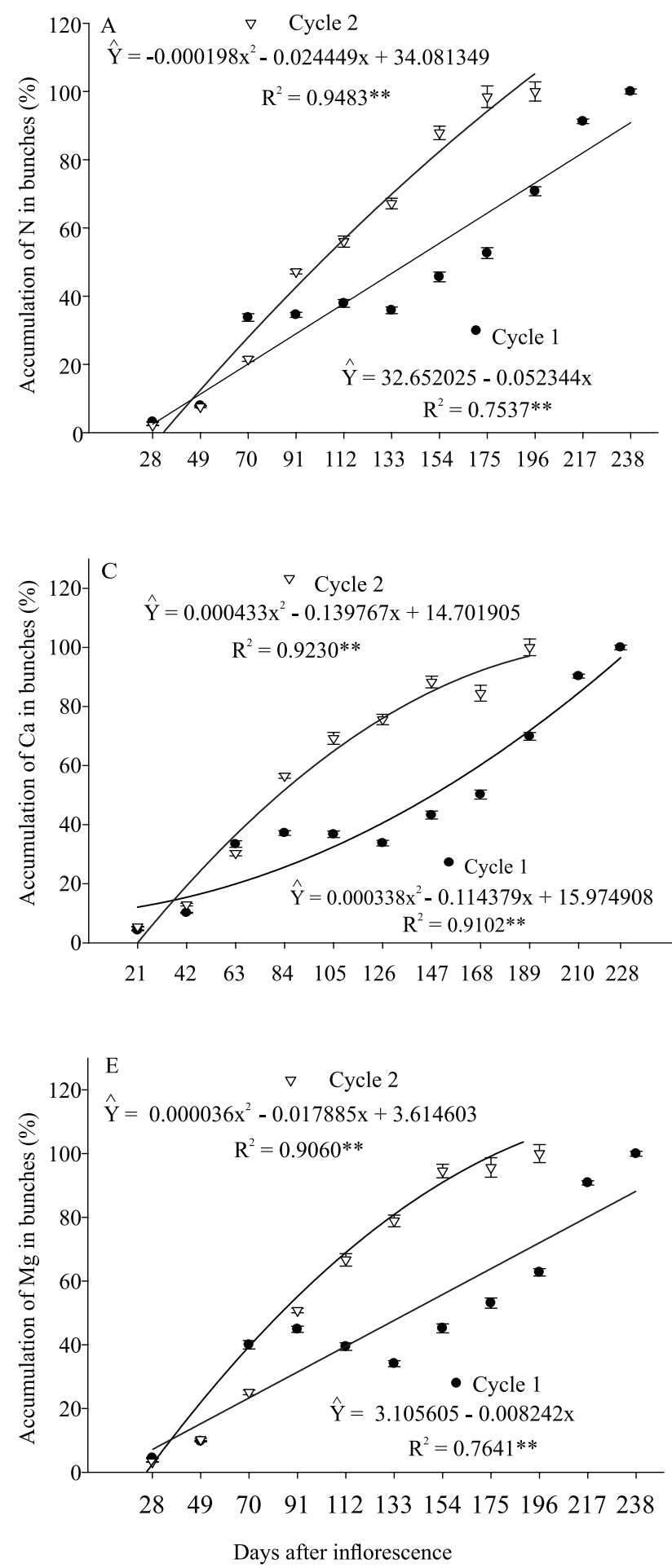

temperatures were registered, with $6^{\circ} \mathrm{C}$ difference in the maximum, mean and minimum temperatures.
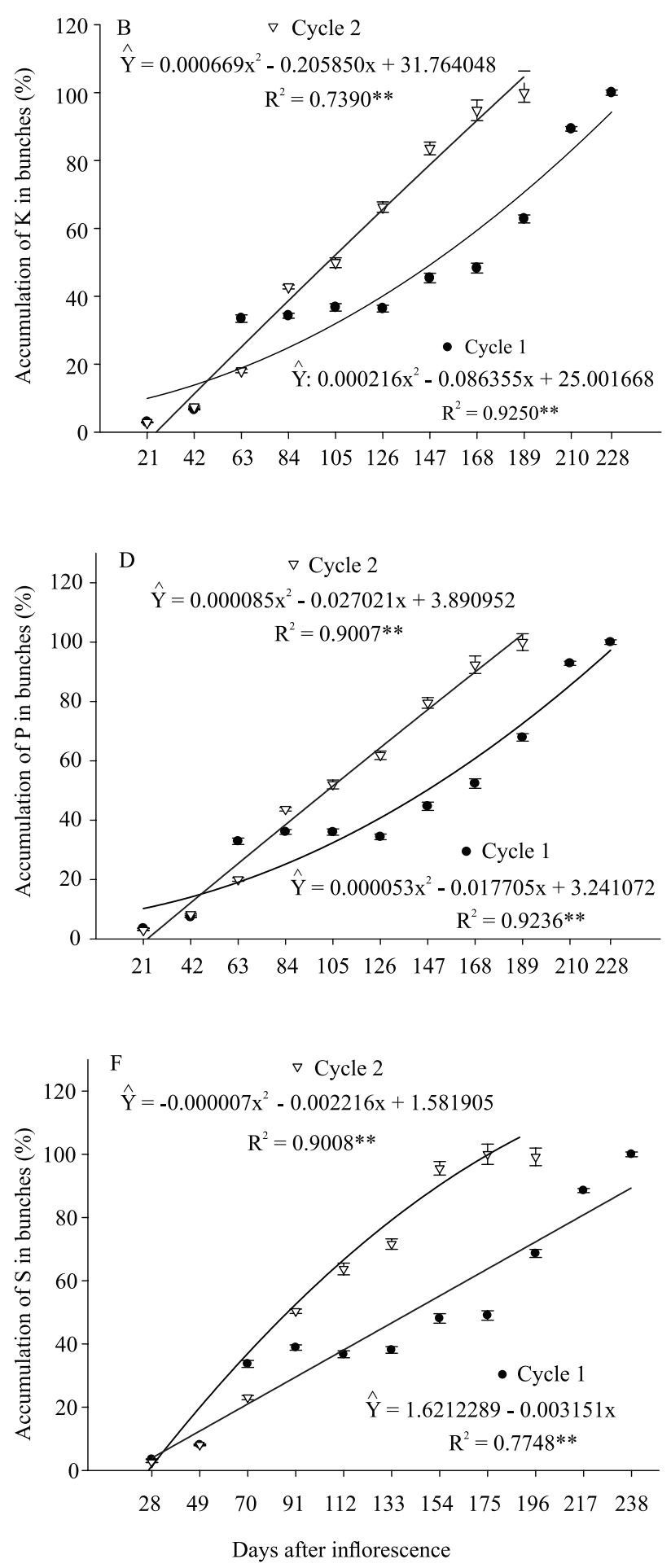

Figure 5. Macronutrient accumulation in 'Bragantina' black pepper (Piper nigrum) bunches over two reproductive cycles: (A), N; (B), K; (C), Ca; (D), P; (E), Mg; and (F), S. The first reproductive cycle occurred from 04/17/2017 to 11/13/2017, and the second one, from 11/13/2017 to 04/30/2018, in São Mateus, in the state of Espírito Santo, Brazil. The vertical bars represent the standard deviation. 
Black pepper plants tolerate a temperature range between 10 and $40^{\circ} \mathrm{C}$, but the optimum temperature is between 23 and $32^{\circ} \mathrm{C}$, with $28^{\circ} \mathrm{C}$ being the average (Sivaraman et al., 1999). Studies have shown that the climatic variables, maximum and minimum temperatures, in Kerala, in India, have a significant effect on the production of black pepper (Kandiannan et al., 2011), and the maximum and minimum temperatures may influence the production more than precipitation in irrigated crops (Krishnamurthy et al., 2011). In Kerala, a study showed also that most cultivars of black pepper showed a slight reduction in the accumulation of leaf area, plant height, and photosynthetic rate, at two degrees above room temperature, indicating that climate change, no matter how small it is, influences the crop behavior (Kandiannan et al., 2011).

Determining the macronutrient dynamics through crop cycles of black pepper makes it possible to understand the crop nutritional demands. As the macronutrient content in black pepper leaves and bunches depend on the crop stage, such variation should be considered for the planning of the fertilization management.

\section{Conclusions}

1. The leaf-macronutrient contents vary throughout the periods within the reproductive cycle of black pepper (Piper nigrum), and $\mathrm{K}$ and $\mathrm{Mg}$ vary more than $\mathrm{N}, \mathrm{P}, \mathrm{Ca}$, and $\mathrm{S}$; the highest-macronutrient contents in the bunches occur in the inflorescence phase, with less expressive rates of macronutrients at the end of the fruit formation cycle.

2. N, K, and $\mathrm{Ca}$ are the most accumulated macronutrients in the black pepper bunches, followed by $\mathrm{P}, \mathrm{Mg}$, and $\mathrm{S}$; macronutrient accumulation curves behave in linear and quadratic ways showing a lower content in the inflorescence phase, followed by a constant increase until the end of the reproductive cycle, when the macronutrients reach their maximum accumulation point.

\section{Acknowledgments}

To Fundação de Amparo à Pesquisa e Inovação do Espírito Santo (Fapes), for financial support; to Universidade Federal do Espírito Santo (UFES/ Ceunes), for providing the required facilities; and to Mr. Zenor Quinquim, for assistance.

\section{References}

ABUKAWSAR, M.M.; SALEH-E-IN, M.M.; AHSAN, M.A.; RAHIM, M.M.; BHUIYAN, M.N.H.; ROY, S.K.; GHOSH, A.; NAHER, S. Chemical, pharmacological and nutritional quality assessment of black pepper (Piper nigrum L.) seed cultivars. Journal of Food Biochemistry, v.42, e12590, 2018. DOI: https://doi.org/10.1111/jfbc.12590.

ALVARES, C.A.; STAPE, J.L.; SENTELHAS, P.C.; GONÇALVES, J.L. de M.; SPAROVEK, G. Köppen's climate classification map for Brazil. Meteorologische Zeitschrift, v.22, p.711-728, 2013. DOI: https://doi.org/10.1127/09412948/2013/0507.

ANN, Y.C. Determination of nutrient uptake characteristic of black pepper (Piper nigrum L.). Journal of Agricultural Science and Technology, v.2, p.1091-1099, 2012.

AULAR, J.; NATALE, W. Nutrição mineral e qualidade do fruto de algumas frutíferas tropicais: goiabeira, mangueira, bananeira e mamoeiro. Revista Brasileira de Fruticultura, v.35, p.1214-1231, 2013. DOI: https://doi.org/10.1590/S0100-29452013000400033.

BUTT, M.S.; PASHA, I.; SULTAN, M.T.; RANDHAWA, M.A.; SAEED, F.; AHMED, W. Black pepper and health claims: a comprehensive treatise. Critical Reviews in Food Science and Nutrition, v.53, p.875-886, 2013. DOI: https://doi.org/10.1080/10 408398.2011.571799.

COVRE, A.M.; PARTELLI, F.L.; BONOMO, R.; TOMAZ, M.A.; RAMALHO, J.C. Impacts of water availability on macronutrients in fruit and leaves of conilon coffee. Pesquisa Agropecuária Brasileira, v.53, p.1025-1037, 2018. DOI: https://doi.org/10.1590/ S0100-204X2018000900006.

COVRE, A.M.; RODRIGUES, W.P.; VIEIRA, H.D.; BRAUN, H.; RAMALHO, J.C.; PARTELLI, F.L. Nutrient accumulation in bean and fruit from irrigated and nonirrigated Coffea canephora cv. Conilon. Emirates Journal of Food and Agriculture, v.28, p.402-409, 2016. DOI: https://doi.org/10.9755/ejfa.2016-04-341.

DUBBERSTEIN, D.; PARTELLI, F.L.; DIAS， J.R.M.; ESPINDOLA, M.C. Concentration and accumulation of macronutrients in leaf of coffee berries in the Amazon, Brazil. Australian Journal of Crop Science, v.10, p.701-710, 2016. DOI: https://doi.org/10.21475/ajcs.2016.10.05.p7424.

FERREIRA, D.F. Sisvar: a computer analysis system to fixed effects split plot type designs. Revista Brasileira de Biometria, v.37, p.529-535, 2019. DOI: https://doi.org/10.28951/rbb.v37i4.450.

GOMES JÚNIOR, G.A.; PEREIRA, R.A.; SACRAMENTO, C.K. do; SOUZA JÚNIOR, J.O. de. Extração e exportação de nutrientes em frutos de gravioleira. Revista Ciência Agrícola, v.16, p.80-84, 2018. DOI: https://doi.org/10.28998/rca.v16i2.4649.

HOREL, Á.; GELYBÓ, G.; POTYÓ, I.; POKOVAI, K.; BAKACSI, $Z$. Soil nutrient dynamics and nitrogen fixation rate changes over plant growth in temperate soil. Agronomy, v.9, art.179, 2019. DOI: https://doi.org/10.3390/agronomy9040179. 
INTERNATIONAL PEPPER COMMUNITY. Pepper statistical yearbook 2018. Available at: $<$ http://www.ipcnet.org/ psy/?p=d\&y=2018>. Accessed on: 16 Mar. 2018.

IUSS WORKING GROUP WRB. World reference base for soil resources 2014: international soil classification system for naming soils and creating legends for soil maps. Rome: FAO, 2015. 192p.

KANDIANNAN, K.; PARTHASARATHY, U.; KRISHNAMURTHY, K.S.; THANKAMANI, C.K.; SRINIVASAN, V.; AIPE, K.C. Modeling the association of weather and black pepper yield. Indian Journal of Horticulture, v.68, p.96-102, 2011.

KRISHNAMURTHY, K.S.; KANDIANNAN, K.; SIBIN, C.; CHEMPAKAM, B.; ANKEGOWDA, S.J. Trends in climate and productivity and relationship between climatic variables and productivity in black pepper (Piper nigrum). Indian Journal of Agricultural Sciences, v.81, p.729-733, 2011.

LAVIOLA, B.G.; MARTINEZ, H.E.P.; SOUZA, R.B. de; VENEGAS, V.H.A. Dinâmica de $\mathrm{N}$ e $\mathrm{K}$ em folhas, flores e frutos de cafeeiro arábico em três níveis de adubação. Bioscience Journal, v.22, p.33-47, 2006.

LSPA. LEVANTAMENTO SISTEMÁTICO DA PRODUÇÃO AGRÍCOLA: pesquisa mensal de previsão e acompanhamento das safras agrícolas no ano civil. Rio de Janeiro: IBGE, v.30, p.182, 2017. Disponível em: <https://biblioteca.ibge.gov.br/index. $\mathrm{php} /$ biblioteca-catalogo? view $=$ detalhes $\& \mathrm{id}=76>$. Acesso em: 7 abr. 2020 .

MACINTOSH, K.A.; DOODY, D.G.; WITHERS, P.J.A.; MCDOWELL, R.W.; SMITH, D.R.; JOHNSON, L.T.; BRUULSEMA, T.W.; O'FLAHERTY, V.; MCGRATH, J.W. Transforming soil phosphorus fertility management strategies to support the delivery of multiple ecosystem services from agricultural systems. Science of the Total Environment, v.649, p.90-98, 2019. DOI: https://doi.org/10.1016/j.scitotenv.2018.08.272.

PANDEY, R. Mineral nutrition of plants. In: BAHADUR, B.; RAJAM, M.V.; SAHIJRAM, L.; KRISHNAMURTHY, K.V. (Ed.). Plant Biology and Biotechnology. New Delhi: Springer, 2015. p.499-538. DOI: https://doi.org/10.1007/978-81-322-2286-6_20.

PARTELLI, F.L. Nutrition of black pepper (Piper nigrum L.) - A Brazilian experience. Journal of Spices and Aromatic Crops, v.18, p.73-83, 2009.

PARTELLI, F.L.; ESPINDULA, M.C.; MARRÉ, W.B.; VIEIRA, H.D. Dry matter and macronutrient accumulation in fruits of Conilon coffee with different ripening cycles. Revista Brasileira de Ciência do Solo, v.38, p.214-222, 2014. DOI: https://doi.org/10.1590/S0100-06832014000100021.

PREZOTTI, L.C.; GOMES, J.A.; DADALTO, G.G.; OLIVEIRA, J.A. (Ed.). Manual de recomendação de calagem e adubação para o Estado do Espírito Santo: $5^{\mathrm{a}}$ aproximação. Vitória: SEEA: Incaper: Cedagro, 2007. 301p.

REHMAN, A.; MEHMOOD, M.H.; HANEEF, M.; GILANI, A.H.; ILYAS, M.; SIDDIQUI, B.S.; AHMED, M. Potential of black pepper as a functional food for treatment of airways disorders. Journal of Functional Foods, v.19, p.126-140, 2015. DOI: https://doi.org/10.1016/j.jff.2015.09.006.

SANTOS, H.G. dos; JACOMINE, P.K.T.; ANJOS, L.H.C. dos; OLIVEIRA, V.Á. de; LUMBRERAS, J.F.; COELHO, M.R.; ALMEIDA, J.A. de; ARAÚJO FILHO, J.C. de; OLIVEIRA, J.B. de; CUNHA, T.J.F. Sistema brasileiro de classificação de solos. 5.ed. rev. e ampl. Brasília: Embrapa, 2018.

SÃO JOSÉ, A.R.; PRADO, N.B. do; BOMFIM, M.P.; REBOUÇAS, T.N.H.; MENDES, H.T.A. e. Marcha de absorção de nutrientes em anonáceas. Revista Brasileira de Fruticultura, v.36, p.176183, 2014. Número especial. DOI: https://doi.org/10.1590/S010029452014000500021.

SERRANO, L.A.L.; LIMA, I. de M.; MARTINS, M.V.V. A cultura da pimenteira-do-reino do estado do Espírito Santo. Vitória: Incaper, 2006. 34p.

SIVARAMAN, K.; KANDIANNAN, K.; PETER, K.V.; THANKAMANI, C.K. Agronomy of black pepper (Piper nigrum L.) - a review. Journal of Spices and Aromatic Crops, v.8, p.118, 1999.

SRINIVASAN, K. Black pepper and its pungent principlepiperine: a review of diverse physiological effects. Critical Reviews in Food Science and Nutrition, v.47, p.735-748, 2007. DOI: https://doi.org/10.1080/10408390601062054.

TAIZ, L.; ZEIGER, E.; MØLlER, I.M.; ANGUS, M. Plant physiology and development. $6^{\text {th }}$ ed. Sunderland: Sinauer Associates Inc., 2014. 761p.

TASLEEM, F.; AZHAR, I.; ALI, S.N.; PERVEEN, S.; MAHMOOD, Z.A. Analgesic and anti-inflammatory activities of Piper nigrum L. Asian Pacific Journal of Tropical Medicine, v.7, p.S461-S468, 2014. Suppl.1. DOI: https://doi.org/10.1016/ S1995-7645(14)60275-3.

TEIXEIRA, P.C.; DONAGEMMA, G.K.; FONTANA, A.; TEIXEIRA, W.G. (Ed.). Manual de métodos de análise de solo. 3. ed. rev. e ampl. Brasília: Embrapa, 2017. 573p.

VELOSO, C.A.C.; CARVALHO, E.J.M. Absorção e extração de alguns nutrientes pela cultivar 'guajarina' de pimentado-reino. Scientia Agricola, v.56, p.443-447, 1999. DOI: https://doi.org/10.1590/s0103-90161999000200026.

VELOSO, C.A.C.; CARVALHO, E.J.M.; MALAVOLTA, E.; MURAOKA, T. Resposta de cultivares de pimenta-do-reino aos nutrientes NPK em um Latossolo Amarelo da Amazônia Oriental. Scientia Agricola, v.57, p.343-347, 2000. DOI: https://doi.org/10.1590/S0103-90162000000200023.

VIÉGAS, I. de J.M.; SOUSA, G.O. de; SILVA, A.F. da; CARVALHO, J.G. de; LIMA, M.M. Composição mineral e sintomas visuais de deficiências de nutrientes em plantas de pimenta-longa (Piper hispidinervum C. DC.). Acta Amazonica, v.43, p.43-50, 2013. DOI: https://doi.org/10.1590/S004459672013000100006.

WANG, Y.-H.; MORRIS-NATSCHKE, S.L.; YANG, J.; NIU, H.-M.; LONG, C.-L.; LEE, K.-H. Anticancer principles from medicinal piper (Hú Jiāo) plants. Journal of Traditional and Complementary Medicine, v.4, p.8-16, 2014. DOI: https://doi.org/10.4103/2225-4110.124811. 